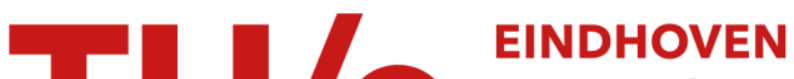 UNIVERSITY OF TECHNOLOGY
}

\section{Full scale demonstration of air-purifying pavement}

Citation for published version (APA):

Ballari, M., \& Brouwers, H. J. H. (2013). Full scale demonstration of air-purifying pavement. Journal of Hazardous Materials, 254-255, 406-414. https://doi.org/10.1016/j.jhazmat.2013.02.012

DOI:

10.1016/j.jhazmat.2013.02.012

Document status and date:

Published: 01/01/2013

\section{Document Version:}

Publisher's PDF, also known as Version of Record (includes final page, issue and volume numbers)

\section{Please check the document version of this publication:}

- A submitted manuscript is the version of the article upon submission and before peer-review. There can be important differences between the submitted version and the official published version of record. People interested in the research are advised to contact the author for the final version of the publication, or visit the $\mathrm{DOI}$ to the publisher's website.

- The final author version and the galley proof are versions of the publication after peer review.

- The final published version features the final layout of the paper including the volume, issue and page numbers.

Link to publication

\section{General rights}

Copyright and moral rights for the publications made accessible in the public portal are retained by the authors and/or other copyright owners and it is a condition of accessing publications that users recognise and abide by the legal requirements associated with these rights.

- Users may download and print one copy of any publication from the public portal for the purpose of private study or research.

- You may not further distribute the material or use it for any profit-making activity or commercial gain

- You may freely distribute the URL identifying the publication in the public portal.

If the publication is distributed under the terms of Article 25fa of the Dutch Copyright Act, indicated by the "Taverne" license above, please follow below link for the End User Agreement:

www.tue.nl/taverne

Take down policy

If you believe that this document breaches copyright please contact us at:

openaccess@tue.nl

providing details and we will investigate your claim. 


\title{
Full scale demonstration of air-purifying pavement
}

\author{
M.M. Ballari*, H.J.H. Brouwers \\ Department of the Built Environment, Eindhoven University of Technology, P.O. Box 513, 5600 MB Eindhoven, The Netherlands
}

H I G H L I G H T S

- The results of a demonstration project for photocatalytic pavement are shown.

- The photocatalytic performance was studied in a street as well as on lab scale.

- The outdoor monitoring was performed in different seasons and weather conditions.

- The $\mathrm{NO}_{x}$ concentration was in average $19 \%$ lowered by the photocatalytic street.

- Under ideal weather conditions the $\mathrm{NO}_{x}$ reduction reached up to $45 \%$.

\section{A R T I C L E I N F O}

\section{Article history:}

Received 21 November 2012

Received in revised form 6 February 2013

Accepted 10 February 2013

Available online 21 March 2013

\section{Keywords:}

Photocatalytic pavement

Full scale demonstration

Air purification

\section{G R A P H I C A L A B S T R A C T}

\begin{abstract}
A B S T R A C T
Experiments concerning a full-scale demonstration of air purifying pavement in Hengelo, The Netherlands, are reported. The full width of the street was provided with concrete pavement containing $\mathrm{TiO}_{2}$ over a length of $150 \mathrm{~m}$ ("DeNO${ }_{x}$ street"). Another part of the street, about $100 \mathrm{~m}$, was paved with normal paving blocks ("Control street"). The outdoor monitoring was done during 26 days for a period exceeding one year, and measured parameters included traffic intensity, $\mathrm{NO}, \mathrm{NO}_{2}$ and ozone concentrations, temperature, relative humidity, wind speed and direction, and the visible and UV light irradiance. Prior and parallel to these field measurements, the used blocks were also measured in the lab to assess their performance. The $\mathrm{NO}_{x}$ concentration was, on average, $19 \%$ (considering the whole day) and $28 \%$ (considering only afternoons) lower than the obtained values in the Control street. Under ideal weather conditions (high radiation and low relative humidity) a $\mathrm{NO}_{x}$ concentration decrease of $45 \%$ could be observed.
\end{abstract}

(C) 2013 Elsevier B.V. All rights reserved.

\section{Introduction}

Nitrogen oxides $\left(\mathrm{NO}_{x}\right)$ are the generic term for a group of highly reactive gases, most of them emitted in air in the form of nitric oxide (NO) and nitrogen dioxide $\left(\mathrm{NO}_{2}\right)$. They are manly formed in combustion processes and cause a wide variety of health and environmental impacts. The $\mathrm{NO}_{x}$ compounds are responsible for

\footnotetext{
* Corresponding author at: Present address: INTEC (Universidad Nacional del Litoral and CONICET), Ruta Nacional N $\mathrm{N}^{\circ}$ 168. Km. 472,5, 3000 Santa Fe, Argentina. Tel.: +54 342 4511546; fax: +54342 4511087 .

E-mail addresses: ballari@santafe-conicet.gov.ar, m.ballari@tue.nl(M.M. Ballari), jos.brouwers@tue.nl (H.J.H. Brouwers).
}

tropospheric ozone and urban smog through photochemical reactions with hydrocarbons. Furthermore, $\mathrm{NO}_{x}$ together with $\mathrm{SO}_{\mathrm{x}}$ (sulfur dioxide and sulfur trioxide) is the major contributor to the "acid rain".

The EU has taken important steps over the past decade leading to a decrease in the emissions to air and water of a number of pollutants. The directive 1999/30/EC [1] establishes limit values and, as appropriate, alert thresholds for concentrations of sulphur dioxide, nitrogen dioxide and oxides of nitrogen, particulate matter and lead in ambient air intended to avoid, prevent or reduce harmful effects on human health and the environment. This directive imposes an annual limit value to $\mathrm{NO}_{2}$ for the protection of human health of $40 \mu \mathrm{g} / \mathrm{m}^{3}$ (about $19.7 \mathrm{ppbv}$ ) and an annual limit value to $\mathrm{NO}_{x}$ for the protection of vegetation of $30 \mu \mathrm{g} / \mathrm{m}^{3}$ (about $17.9 \mathrm{ppbv}$ ). Some 
of the pollutant emissions have since become more or less manageable, although particulates, $\mathrm{NO}_{x}$ and smog are still problematic, especially due to the rapid rate of growth of the transport sector. In consequence of it the $\mathrm{NO}_{x}$ emissions from traffic must be reduced in order to meet European agreements.

Heterogeneous Photocatalytic Oxidation (PCO) represents an emerging environmental control option for the efficient removal of chemical pollutants. This process involves a solid semiconductor catalyst, most often anatase titanium dioxide $\left(\mathrm{TiO}_{2}\right)$, which is activated with ultraviolet light of the appropriate wavelength. To date, a number of researchers have investigated the dynamics of the photocatalysis of nitrogen oxides [2-8]. Photocatalytic oxidation of $\mathrm{NO}_{x}$ offers the following distinctive advantages: (1) no extra reactants are required and $(2) \mathrm{NO}_{x}$ is converted to nitrates, a significantly less harmful material.

The development of innovative materials that can be easily applied on structures, with both de-soiling and de-polluting properties, is a significant step towards improvements of air quality. The use of $\mathrm{TiO}_{2}$ photocatalyst in combination with cementitious and other construction materials has shown a favourable effect in the removal of air pollutants [9]. In recent years, a wide number of laboratory scale tests have been performed, under different experimental conditions, in order to evaluate the $\mathrm{NO}_{x}$ degradation properties of $\mathrm{TiO}_{2}$ photocatalytic materials [10-19].

So far some projects were working on innovative solutions for improving air quality employing photocatalytic materials in European roads: Air Quality Innovation Programme (IPL) in the Netherlands [20], the New Road Construction Concepts (NR2C) [21] and Photocatalytic Innovative Coverings Applications for Depollution (PICADA) [22]. Real scale studies in streets or canyons have proven significant reductions of $\mathrm{NO}_{x}$ in Belgium, in Italy and in France $[15,23,24]$.

In the present paper, the results of the air quality measurements performed in the Castorweg street in Hengelo City (The Netherlands) before and after its modification (Fig. 1) are presented in order to evaluate the photocatalytic effect of pavement blocks containing titanium dioxide over the $\mathrm{NO}_{x}$ reduction.

\section{Methodology}

A new demonstration project about the air purifying pavement was performed in Hengelo, Province of Overijssel, The Netherlands. This project was executed from January 2008 till July 2011, with financial support from the Province of Overijssel (The Netherlands), and was jointly executed by the University of Twente, Eindhoven University of Technology, Hengelo Municipality and Struyk Verwo Infra. The street Castorweg in Hengelo was covered with the photocatalytic concrete blocks produced by Struyk Verwo Infra. With the purpose of evaluating the effect of the photocatalytic blocks over the degradation of nitrogen compounds, an air quality monitoring program was carried out in this street. The methodology for the air quality monitoring was established after consulting and by using advice from TNO (The Netherlands), Catholic University of Louvain (Belgium) and the RIVM (National Institute for Public Health and the Environment in The Netherlands) [25].

The modified street ("DeNO ${ }_{x}$ street") covered with photocatalytic blocks over the entire width of the street (about $5 \mathrm{~m}$ ) and approximately $150 \mathrm{~m}$ long was compared with a part of the street ("Control street") with normal blocks of about $100 \mathrm{~m}$ long with identical traffic volume and therefore pollution conditions (Fig. 2). The $\mathrm{DeNO}_{x}$ blocks applied in the Castorweg consist of concrete double layer blocks with a $70 \mathrm{~mm}$ in height lower layer and with an active upper layer of $5 \mathrm{~mm}$ with $\mathrm{TiO}_{2}$. The size of the blocks applied in the street is $120 \mathrm{~mm} \times 220 \mathrm{~mm}$. Periodically, the used concrete blocks in the street were tested in the lab according to ISO 22197-1:2007 [26] to assess their performance.
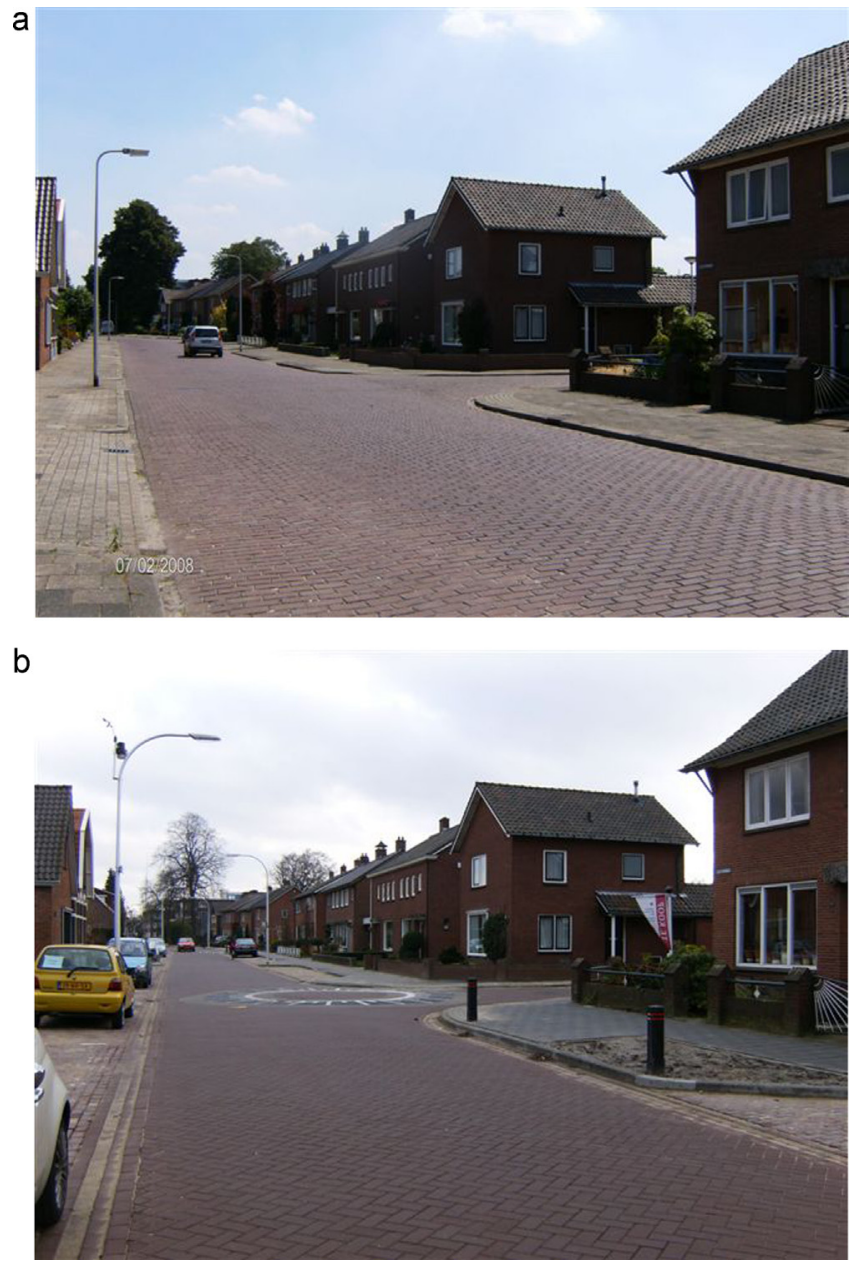

Fig. 1. Castorweg street in Hengelo (The Netherlands). a) Before modification. b) After modification.

Regarding the chronology of this research project, the 1 st of December of 2006 the project proposal was submitted to the Province of Overijssel for its assessment and it was approved the 21 st of December of 2007. The original plan forecasted the street to be rebuilt with the new concrete blocks by the end of 2008 . However, due to some delays in the construction and encountered soil contamination, the remodelling of the street with the $\mathrm{DeNO}_{x}$ blocks finished by the end of October 2009.

The outdoor air quality monitoring started before the precast concrete blocks were placed in December 2008 and continued till July 2011. After the applications of the $\mathrm{DeNO}_{x}$ blocks in November 2009, the first monitoring in the street together with associated laboratory tests of the blocks did not show a significant decrease of the $\mathrm{NO}_{x}$ concentration. Therefore, in order to increase the performance of the photocatalytic activity of the blocks, a coating made with a suspension of $\mathrm{TiO}_{2}$ was subsequently sprayed on the street. According to the supplier, the coating was prepared as $4 \%(\mathrm{w} / \mathrm{w})$ $\mathrm{TiO}_{2}$ water suspension, and $50 \mathrm{~L}$ of suspension were employed in $750 \mathrm{~m}^{2}$ of street, giving $2.67 \mathrm{~g} / \mathrm{m}^{2}$ of $\mathrm{TiO}_{2}$. Carbon doped $\mathrm{TiO}_{2}$ from Kronos International was used.

The first coating was applied in May 2010 during spring time giving good results in the lab as well in the field. However, after 2.5 months of normal outdoor exposition, the coating was lost due to normal wearing, vehicles, weather, etc. [27] or solids were deposited on the surface (e.g. dust or from tires) and the photocatalytic efficiency decreased to the original values before the coating. Then, a second coating was applied in September 2010 with an improved durability. After 1.5 months of exposition of the 


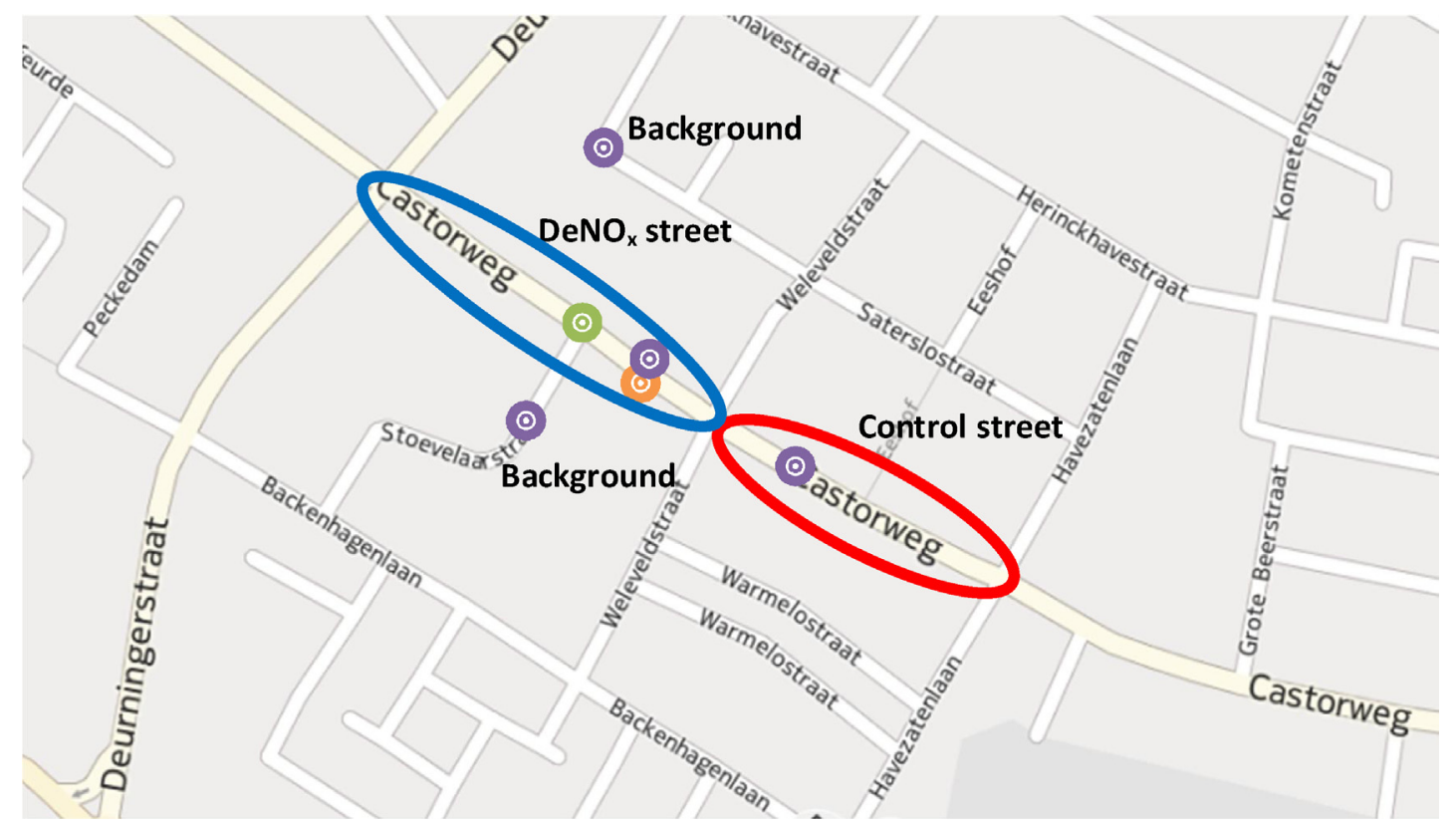

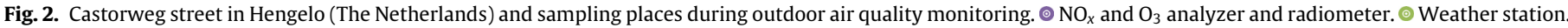
○ Traffic volume counter. Sampling position in DeNO ${ }_{x}$ street: $52^{\circ} 16^{\prime} 31.99^{\prime \prime} \mathrm{N} \mathrm{6}^{\circ} 48^{\prime} 21.29^{\prime \prime}$. Sampling position in Control street: $52^{\circ} 16^{\prime} 30.81^{\prime \prime} \mathrm{N}^{\circ} 48^{\prime} 24.57^{\prime \prime} \mathrm{E}$.

second coating, still a good photocatalytic performance was found. However, almost 11 month after the application of the last coating the low original block photocatalytic performance was found again.

\subsection{Laboratory experiments}

Prior and parallel to the outdoor measurements, the used blocks in the street were tested at laboratory scale according to the standard ISO 22197-1:2007 [26] for the nitric oxide (NO) photocatalytic removal. The applied experimental device is composed of a planar reactor cell housing the concrete block sample, a suitable UV-A light source, a chemiluminescent $\mathrm{NO}_{x}$ analyzer, and an appropriate gas supply [28].

The testing conditions stated in the above mentioned standard were: $10 \mathrm{~W} / \mathrm{m}^{2}$ of UV irradiance, $50 \%$ of relative humidity, $3 \mathrm{l} / \mathrm{min}$ of flow rate, inlet NO concentration equal to $1 \mathrm{ppm}$, an exposed surface equal to $100 \mathrm{~mm} \times 200 \mathrm{~mm}$, and a reactor height of $3 \mathrm{~mm}$, giving therefore a residence time of $1.2 \mathrm{sec}$. For more details of the experimental setup employed in this study see [28].

In addition, the upper layer of these blocks was analyzed with $\mathrm{X}$ - ray fluorescence (XRF).

\subsection{Outdoor monitoring}

The following parameters that could have effect over the photocatalytic performance of the blocks were measured in the street: temperature, wind speed, wind direction, air pressure, relative humidity, $\mathrm{NO}$ concentration, $\mathrm{NO}_{2}$ concentration, irradiance (visible and UV light), traffic volume, and $\mathrm{O}_{3}$ concentration.

The most important features of the used equipment are listed as follows: (i) Weather station Wireless Vantage Pro2 Station. The Vantage Pro2 Wireless Weather Station is suitable to measure temperature, wind speed, wind direction, pressure, relative humidity, solar radiation and among others weather parameters. (ii) Radiometer UV-VIS Radiometer RM - 12 Dr. Groebel UV-Elektronik GmbH. The radiometer RM-112 can measure irradiances and illuminances in different UV and visible spectral ranges employing the respective sensors: UV-A sensor from 315 to $400 \mathrm{~nm}$ and Blue-Green visible light from 400 to $570 \mathrm{~nm}$. (iii) $\mathrm{NO}_{x}$ analyzers Ambient $\mathrm{NO}_{x}$ Monitor Horiba APNA - 370 and APNA -360. The Ambient $\mathrm{NO}_{x}$ Monitor Horiba APNA-370 and APNA-360 use the chemiluminescence principle and the referential calculation method to measure continuously $\mathrm{NO}_{x}, \mathrm{NO}$, and $\mathrm{NO}_{2}$. (iv) $\mathrm{O}_{3}$ Analyzer Aeroqual Series 500 Multi-Sensor Handheld Gas Monitor. This gas sensor is a replaceable head system and it can measure ultra low ozone concentration from 0 to $0.15 \mathrm{ppm}$. (v) Traffic volume. The Municipality of Hengelo placed in some period of time a radar dispositive to count the traffic. This radar not only counts the number of vehicles per unit of time, but also can measure the speed, direction and size of the vehicles.

The air quality monitoring was performed in different seasons in order to obtain representative data during a year (in total 26 measurements). Some of these measurements were done before the street modification to obtain background information. According to the season, the weather conditions and the electric energy availability provided by the Castorweg residents, the experiments used to start between 8:30 and 9:30 am and they used to last till between 4:00 and 5:00 p.m.

The $\mathrm{NO}_{x}$ analyzer APNA - 370 and the radiometer were placed mostly in the modified street during the measurement day (with the exception of few times when both $\mathrm{NO}_{x}$ analyzers were exchanged), changing the height sampling each one hour starting at $150 \mathrm{~cm}$, then at $30 \mathrm{~cm}$ and finally at $5 \mathrm{~cm}$ (Fig. 2). Regarding the $\mathrm{O}_{3}$ analyzer and the second $\mathrm{NO}_{x}$ analyzer APNA - 360, in the course of the selected days their measurements were done in different places in the Control street at the same height as in the modified street. In the morning the $\mathrm{O}_{3}$ and APNA-360 analyzers started to measure in one of the background streets (see Fig. 2). After half an hour they were moved to the Control street and then every one hour the $\mathrm{O}_{3}$ analyzer was moved between the Control and $\mathrm{DeNO}_{x}$ street. The sampling in the Control street can be assumed with similar conditions to the sampling position in the modified street (direction, buildings height, street width, closeness, traffic volume). The sampling places were around $4 \mathrm{~m}$ from the centre of the traffic lane and at least $1.5 \mathrm{~m}$ from the nearest building [1]. At the end of the day either the background area was monitored again for half an hour or both $\mathrm{NO}_{x}$ analyzers were placed together to check the compatibility of both equipments.

As mentioned before, the $\mathrm{NO}_{x}$ samplings were placed at different heights: $5 \mathrm{~cm}$ (near the active surface), $30 \mathrm{~cm}$ (car exhaust height) and $150 \mathrm{~cm}$ (the breathing zone) in order to evaluate the decontamination effect for difference distance from the active 
Table 1

Laboratory test results of different samples according to ISO 22197-1:2007, using UV and visible light.

\begin{tabular}{|c|c|c|c|c|}
\hline Sample & $X_{\text {NO,UV }}[\%]$ & $X_{\mathrm{NO}_{x}, \mathrm{UV}}[\%]$ & $X_{\mathrm{NO}, \mathrm{vis}}[\%]$ & $X_{\mathrm{NO}_{x}, \text { vis }}[\%]$ \\
\hline Original stone & 12.5 & 9.6 & - & - \\
\hline First coating & 47.3 & 38.6 & 7.7 & 6.9 \\
\hline 2.5 months exposition & 13.9 & 4.1 & - & - \\
\hline Second coating & 60.2 & 37.4 & - & - \\
\hline 1.5 months exposition & 43.9 & 19.1 & - & - \\
\hline 11 months exposition & 3.6 & 2.8 & - & - \\
\hline
\end{tabular}

$\mathrm{X}=\left(C_{\text {inlet }}-C_{\text {outlet }}\right) / C_{\text {inlet }} \times 100$.

surface. The radiometer measurement was performed over the concrete surface. The weather conditions (temperature, pressure, wind speed and direction, and relative humidity) were measured near the air sampling place of the $\mathrm{DeNO}_{x}$ street at $2 \mathrm{~m}$ above the ground (Fig. 2).

\section{Results}

\subsection{Laboratory results}

Table 1 shows the $\mathrm{NO}$ and $\mathrm{NO}_{x}$ (total of nitrogen oxides, predominantly $\mathrm{NO}+\mathrm{NO}_{2}$ ) conversion at laboratory scale employing different concrete blocks samples taken from the $\mathrm{DeNO}_{x}$ street. As mentioned before the original double layer block presented a low performance due to its low $\mathrm{TiO}_{2}$ content. Nevertheless, the first coating applied in the street showed an overall $\mathrm{NO}_{x}$ degradation of $38.6 \%$ at laboratory scale. In addition, this coating has presented activity under visible light. However, 2.5 months later some samples from the street were removed and the original low degradation was found again during the lab test. Then, a second coating was applied in September 2010 increasing again the photocatalytic $\mathrm{NO}_{x}$ reduction to $37.6 \%$, that after 1.5 months of its application was only reduced to $19.1 \%$. In July 2011, after 11 months of outdoor exposition, almost no $\mathrm{NO}_{x}$ abating ability was found because of the ageing of the coating.

In addition, previous to the photocatalytic coating application, the upper layer of the original block was analyzed with X-ray fluorescence (XRF), showing a $\mathrm{TiO}_{2}$ content of $0.59 \%$ by weight in the layer volume. According to experience with other photocatalytic blocks, this content is too low to achieve the necessary NO degradation of $40-50 \%$ in the lab [29].

\subsection{Overall field results}

The average weather conditions for each measuring day (average temperature, average relative humidity, average wind speed and average solar radiation) of the air monitoring in the Castorweg performed as from December 2008 till July 2011 are shown in Table 2. The UV-A irradiance measured by the radiometer was around $3 \%$ of the total solar radiation.

The traffic volume was determined in the Castorweg during three different times (in December 2008, February 2009 and June 2010) by the traffic counter radar. The average results for the number of vehicles per unit of time, speed, direction and size of the cars are shown in Table 3. An average of $110 \pm 14$ vehicles per hour was determined in the Castorweg.

In order to evaluate the $\mathrm{NO}_{x}$ reduction effect by the photocatalytic blocks in the Castorweg, the relative and absolute contamination reduction by the $\mathrm{DeNO}_{x}$ street can be defined:

Relative Reduction [\%] $=\frac{\mathrm{C}_{\mathrm{NO}_{x}} \text {, Control }-C_{\mathrm{NO}_{x}, \mathrm{DeNO}_{x}}}{C_{\mathrm{NO}_{x}} \text {, Control }} \times 100$

Absolute Reduction $[\mathrm{ppm}]=C_{\mathrm{NO}_{x}}$, Control $-C_{\mathrm{NO}_{x}}$, DeNO where $C_{\mathrm{NO}_{x}}$, Control and $C_{\mathrm{NO}_{x}}$, DeNO $\mathrm{N}_{x}$ are the average concentrations of $\mathrm{NO}_{x}$ in ppm measured in the Control street and in the $\mathrm{DeNO}_{x}$ street, respectively.

Table 4 shows the average of absolute and relative $\mathrm{NO}_{x}$ reduction, and the average concentration of $\mathrm{NO}_{x}$ for every measuring day before the modification of the street and before the applications of the photocatalytic coatings, and including some measurements performed when the coatings lost their abating ability and during rainy and very windy days (26th of May, 15th of September and 21 st of October, 2010). The same results are shown in Table 5 for the outdoor monitoring performed under the presence of a photocatalytic surface after the first and second coating applications in the Castorweg, respectively.

It is worthwhile to mention that before the street coating in May 2010, and including some days in July and August when the activity of the coating was lost according to lab test, the average $\mathrm{NO}_{x}$ concentrations in the $\mathrm{DeNO}_{x}$ street is about 3.5\% higher than in the Control street. Including all the measurements when no photocatalytic effect can be considered (without photocatalytic coating and rainy and very windy days) the average $\mathrm{NO}_{x}$ difference between the both streets is $-5.8 \%$ with a standard deviation $\sigma$ equal to $22.26 \%$, meaning that the concentration of $\mathrm{NO}_{x}$ in the $\mathrm{DeNO}_{x}$ street is $5.8 \%$ higher than in the Control street when no photocatalytic effect is present. If the outliers are taken out (26/05/2010 and 03/08/2010), this difference is reduced to $-0.4 \%$ ( $\sigma=16.80 \%$ ).

On the other hand, the measurements performed after the application of the coatings and when there was certainly photocatalytic activity in the street have shown that the concentration in the $\mathrm{DeNO}_{x}$ street is $19.2 \%(\sigma=17.81 \%)$ in average lower than in the Control street. However, if the average of the $\mathrm{NO}_{x}$ concentration is calculated only in the afternoon, this difference increased to $28.3 \%$ ( $\sigma=19.97 \%$ ). This could be due to in the afternoon the solar radiation and temperature increases, leading the relative humidity becomes lower and the street drier than in the morning. This set of conditions will favour the $\mathrm{NO}_{x}$ reduction because when the blocks are dry the pollutants can be adsorbed over the active sites of $\mathrm{TiO}_{2}$ and therefore can react. On the other hand, when the radiation is higher the activation of the photocatalyst is improved. And for a lower relative humidity in the atmosphere, the pollutants have less competition with water for the active sites, also increasing the $\mathrm{NO}_{x}$ reaction rate $[28,30]$.

Nevertheless, it is hard to make conclusions about the different factors effects over the efficiency of the $\mathrm{NO}_{x}$ removal observing the reduction results of different measurement days. This is because from one day to the other, several parameters changed simultaneously and therefore it is not possible to analyze the effect of only one parameter. In order to predict the effect of different factors independently over the $\mathrm{NO}_{x}$ degradation a CFD model would be needed [31,32]. On the other hand, due to the application of the photocatalytic coating that is not very durable under normal outdoor exposition, the photocatalytic performance decreases with the ageing of the coating. Therefore, the street does not present constant photocatalytic efficiency from one measuring day to the other. In the next paragraph, some measurements results will be discussed in more detail. 
Table 2

Average weather conditions during the outdoor monitoring.

\begin{tabular}{|c|c|c|c|c|c|c|}
\hline Date & Solar radiation $\left(\mathrm{W} / \mathrm{m}^{2}\right)$ & Temperature $\left({ }^{\circ} \mathrm{C}\right)$ & Relative humidity (\%) & Wind speed $(\mathrm{m} / \mathrm{s})$ & Wind direction & General weather condition \\
\hline $12 / 2 / 2009$ & 252.05 & 2.4 & 80.8 & 1.53 & NW & Sunny \\
\hline $13 / 3 / 2009$ & 353.83 & 9.3 & 72.2 & 1.35 & $\mathrm{~W}$ & Partially cloudy \\
\hline $16 / 3 / 2009$ & 142.46 & 6.7 & 86.6 & 0.68 & SSW & Cloudy \\
\hline $17 / 3 / 2009$ & 331.65 & 9.5 & 75.6 & 1.63 & NNE & Partially sunny \\
\hline $2 / 12 / 2009$ & 73.00 & 5.0 & 82.5 & 1.55 & $\mathrm{~S}$ & Cloudy \\
\hline $4 / 12 / 2009$ & 44.02 & 4.3 & 85.7 & 2.19 & SW & Cloudy \\
\hline $3 / 3 / 2010$ & 348.35 & 3.1 & 81.7 & 0.60 & WSW & Partially sunny \\
\hline $4 / 3 / 2010$ & 337.55 & 2.0 & 77.9 & 1.24 & NNW & Partially sunny \\
\hline $18 / 5 / 2010$ & 402.07 & 12.8 & 63.2 & 0.87 & NW & Partially cloudy \\
\hline $19 / 5 / 2010$ & 348.35 & 3.1 & 81.7 & 0.60 & WSW & Partially sunny \\
\hline $20 / 5 / 2010$ & 707.38 & 17.6 & 50.7 & 1.90 & $\mathrm{NE}$ & Sunny \\
\hline $21 / 5 / 2010$ & 694.73 & 17.7 & 60.6 & 1.63 & NNW & Partially sunny \\
\hline $26 / 5 / 2010$ & 329.76 & 11.7 & 52.6 & 1.44 & $\mathrm{E}$ & Cloudy/Rainy \\
\hline $3 / 6 / 2010$ & 744.70 & 19.8 & 46.7 & 1.95 & ENE & Sunny \\
\hline $4 / 6 / 2010$ & 738.89 & 18.9 & 52.6 & 0.90 & ENE & Sunny \\
\hline $8 / 7 / 2010$ & 715.62 & 27.9 & 37.7 & 1.26 & SW & Sunny \\
\hline $3 / 8 / 2010$ & 376.12 & 17.8 & 78.3 & 0.95 & WNW & Partially sunny/Rainy \\
\hline $6 / 8 / 2010$ & 643.42 & 19.2 & 57.0 & 0.85 & WNW & Partially sunny \\
\hline $6 / 9 / 2010$ & 625.17 & 17.2 & 52.3 & 2.69 & SE & Sunny \\
\hline $13 / 9 / 2010$ & 384.16 & 16.2 & 75.7 & 0.93 & WNW & Partially cloudy \\
\hline $15 / 9 / 2010$ & 582.14 & 14.9 & 65.8 & 2.51 & SW & Partially sunny/Windy \\
\hline $22 / 9 / 2010$ & 502.65 & 18.3 & 72.2 & 1.18 & $\mathrm{~S}$ & Sunny \\
\hline $8 / 10 / 2010$ & 133.47 & 15.0 & 86.7 & 1.23 & ESE & Cloudy \\
\hline $11 / 10 / 2010$ & 462.54 & 13.0 & 57.6 & 1.65 & ENE & Sunny \\
\hline $21 / 10 / 2010$ & 240.80 & 7.4 & 80.7 & 1.89 & SW & Cloudy/Rainy \\
\hline $27 / 07 / 2011$ & 509.20 & 20.0 & 70.8 & 0.60 & $\mathrm{NE}$ & Partially sunny \\
\hline
\end{tabular}

Table 3

Traffic information in the Castorweg.

\begin{tabular}{|c|c|c|c|c|}
\hline & $\begin{array}{l}\text { Average number of vehicles/hour } \\
\text { Direction: to Stoevelaarstraat }\end{array}$ & $\begin{array}{l}\text { Average speed }(\mathrm{km} / \mathrm{h}) \\
\text { Direction: to Stoevelaarstraat }\end{array}$ & $\begin{array}{l}\text { Average number of vehicles/hour } \\
\text { Direction: to Weleveldstraat }\end{array}$ & $\begin{array}{l}\text { Average speed }(\mathrm{km} / \mathrm{h}) \\
\text { Direction: to Weleveldstraat }\end{array}$ \\
\hline Motorbikes & 1.32 & 30.17 & 1.66 & 28.73 \\
\hline Light vehicles & 54.43 & 34.80 & 48.63 & 34.10 \\
\hline Middle heavy vehicles & 1.18 & 30.74 & 1.73 & 31.51 \\
\hline Heavy vehicles & 0.34 & 31.26 & 0.26 & 30.11 \\
\hline Total & 57.27 & 34.59 & 52.28 & 33.85 \\
\hline
\end{tabular}

Table 4

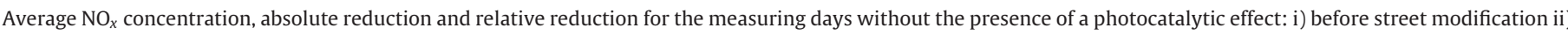

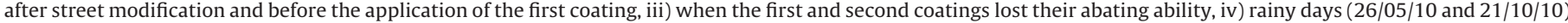
and v) very windy days (15/9/10).

\begin{tabular}{|c|c|c|c|c|c|}
\hline & Date & $C_{\mathrm{NO}_{x}, \mathrm{DeNO}_{x}}(\mathrm{ppm})$ & $C_{\mathrm{NO}_{x}, \text { Control }}(\mathrm{ppm})$ & Absolute reduction (ppm) & Relative reduction (\%) \\
\hline \multirow[t]{4}{*}{ i } & $12 / 2 / 2009$ & 0.0227 & 0.0188 & -0.0039 & -20.87 \\
\hline & $13 / 3 / 2009$ & 0.0149 & 0.0194 & 0.0045 & 23.28 \\
\hline & $16 / 3 / 2009$ & 0.0147 & 0.0156 & 0.0008 & 5.43 \\
\hline & $17 / 3 / 2009$ & 0.0140 & 0.0163 & 0.0023 & 13.97 \\
\hline \multirow[t]{7}{*}{ ii } & $2 / 12 / 2009$ & 0.0621 & 0.0611 & -0.0011 & -1.73 \\
\hline & 4/12/2009 & 0.0225 & 0.0225 & 0.000 & 0.05 \\
\hline & $3 / 3 / 2010$ & 0.0375 & 0.0341 & -0.0034 & -10.09 \\
\hline & $4 / 3 / 2010$ & 0.0121 & 0.0137 & 0.0016 & 12.01 \\
\hline & $18 / 5 / 2010$ & 0.0189 & 0.016 & -0.0029 & -18.32 \\
\hline & $19 / 5 / 2010$ & 0.0076 & 0.008 & 0.0004 & 4.64 \\
\hline & $20 / 5 / 2010$ & 0.0093 & 0.0111 & 0.0018 & 16.39 \\
\hline iv & $26 / 5 / 2010$ & 0.019 & 0.0127 & -0.0062 & -49.1 \\
\hline \multirow[t]{3}{*}{ iii } & $8 / 7 / 2010$ & 0.0156 & 0.0149 & -0.0006 & -4.3 \\
\hline & $3 / 8 / 2010$ & 0.0135 & 0.0091 & -0.0044 & -48.08 \\
\hline & $6 / 8 / 2010$ & 0.0105 & 0.0126 & -0.0022 & -20.71 \\
\hline $\mathrm{v}$ & $15 / 9 / 2010$ & 0.0142 & 0.0106 & -0.0036 & -33.48 \\
\hline iv & $21 / 10 / 2010$ & 0.0386 & 0.0312 & -0.0073 & -23.50 \\
\hline \multirow[t]{3}{*}{ iii } & $27 / 07 / 2011$ & 0.0131 & 0.0152 & 0.0020 & 13.34 \\
\hline & Average & 0.0200 & 0.0190 & -0.0010 & $-5.82(\sigma=22.26)$ \\
\hline & Average without outliers ${ }^{\mathrm{a}}$ & 0.0205 & 0.0201 & -0.0005 & $-0.42(\sigma=16.80)$ \\
\hline
\end{tabular}

\footnotetext{
a $26 / 05 / 2010$ and $03 / 08 / 2010$.
} 
Table 5

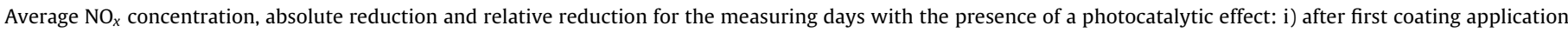
and ii) after second coating application, excluding rainy days (26/05/10 and 21/10/10) and very windy days (15/9/10).

\begin{tabular}{|c|c|c|c|c|c|c|}
\hline & Date & $C_{\mathrm{NO}_{x}, \mathrm{DeNO}_{x}}(\mathrm{ppm})$ & $C_{\mathrm{NO}_{x}, \text { Control }}(\mathrm{ppm})$ & $\begin{array}{l}\text { Absolute reduction } \\
(\mathrm{ppm})\end{array}$ & Relative reduction \% & $\begin{array}{l}\text { Relative reduction } \\
\text { (afternoon) (\%) }\end{array}$ \\
\hline \multirow[t]{3}{*}{ i } & $21 / 5 / 2010$ & 0.0072 & 0.0109 & 0.0043 & 37.62 & 41.33 \\
\hline & $3 / 6 / 2010$ & 0.0061 & 0.0112 & 0.0051 & 45.52 & 47.57 \\
\hline & $4 / 6 / 2010$ & 0.0074 & 0.0102 & 0.0027 & 27.00 & 31.28 \\
\hline \multirow[t]{6}{*}{ ii } & $6 / 9 / 2010$ & 0.0084 & 0.0114 & 0.0029 & 25.94 & 54.95 \\
\hline & $13 / 9 / 2010$ & 0.0134 & 0.0131 & -0.0003 & -2.65 & 11.68 \\
\hline & $22 / 9 / 2010$ & 0.0270 & 0.0283 & 0.0013 & 4.57 & 4.84 \\
\hline & $8 / 10 / 2010$ & 0.0214 & 0.0272 & 0.0058 & 21.27 & 32.71 \\
\hline & $11 / 10 / 2010$ & 0.0181 & 0.0175 & -0.0006 & -3.32 & 2.11 \\
\hline & Average & 0.0136 & 0.0162 & 0.0026 & $19.18(\sigma=17.81)$ & $28.31(\sigma=19.97)$ \\
\hline
\end{tabular}

\subsection{Specific field results}

One of the measurements before the street modification was done on 17 th of March 2009. This day was partially sunny, the average relative humidity was approximately $75.6 \%$, and the average temperature was $9.5^{\circ} \mathrm{C}$.

In Fig. 3 the pollutants (NO, $\mathrm{NO}_{2}$ and $\mathrm{O}_{3}$ ) concentrations measured in the $\mathrm{DeNO}_{x}$ street are shown. These concentrations are compared with those measured by RIVM (National Institute for Public Health and the Environment in The Netherlands) in two regional stations near Hengelo, namely in Hellendoorn and Eibergen. The $\mathrm{O}_{3}$ concentration in the street gradually increases during the day because of homogeneous reactions between oxygen and nitrogen oxides promoted by the solar radiation [33], and has approximately the same value as the $\mathrm{O}_{3}$ concentrations measured by RIVM. It is worth to mention that $\mathrm{O}_{3}$ can also accept electrons of

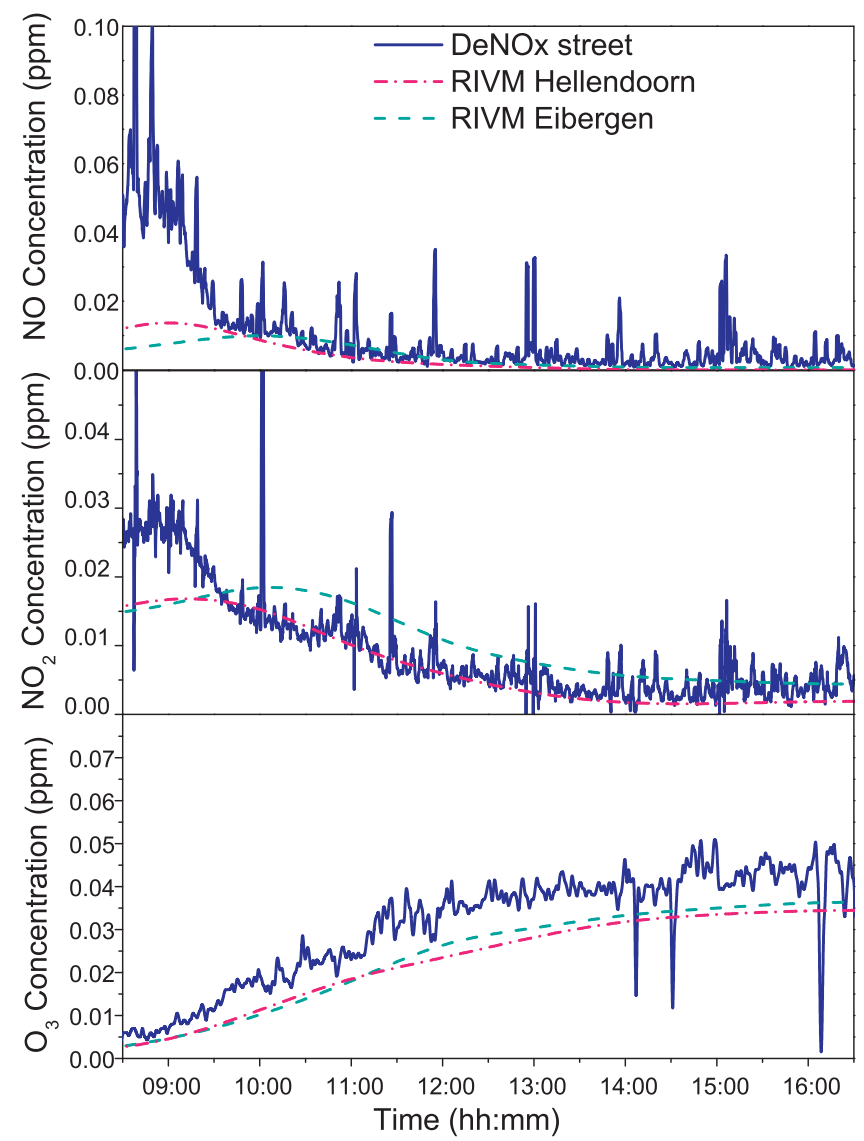

Fig. 3. $\mathrm{NO}, \mathrm{NO}_{2}$ and $\mathrm{O}_{3}$ concentrations measured in the $\mathrm{DeNO}_{x}$ street compared with two RIVM station measurements, 17th of March, 2009, prior to street modification.
$\mathrm{TiO}_{2}$ like $\mathrm{O}_{2}$ and can be decomposed [34]. However, this cannot be observed directly from the measurements due combining effects of $\mathrm{O}_{3}$ photogeneration and degradation by $\mathrm{NO}_{x}$ and $\mathrm{TiO}_{2}$. The $\mathrm{NO}_{x}$ concentration in the street is higher than at the RIVM measuring points, with much higher peaks which can be contributed to passing traffic.

Fig. 4 shows the $\mathrm{NO}_{x}$ concentration measured in the $\mathrm{DeNO}_{x}$ street together with the $\mathrm{NO}_{x}$ concentration measured in the Control street (Fig. 4(a)) and in the background street (Fig. 4(b)). Because the background street is less busy than the Castorweg, the $\mathrm{NO}_{x}$ concentration is significantly lower there. On the other hand, the
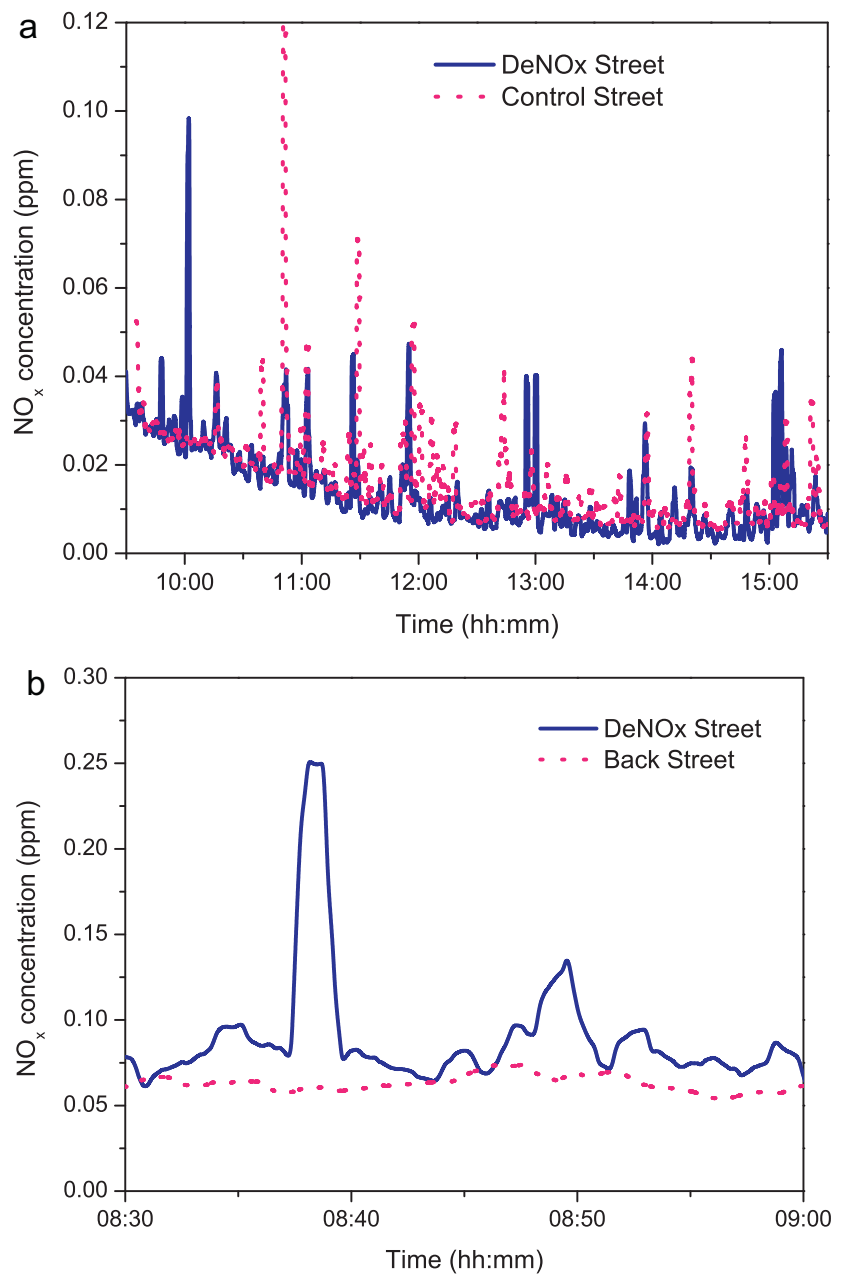

Fig. 4. $\mathrm{NO}_{x}$ concentration measured in the DeNO $\mathrm{N}_{x}$ street compared with: (a) $\mathrm{NO}_{x}$ concentration measured in the Control street, (b) $\mathrm{NO}_{x}$ concentration measured in the background street, 17th of March, 2009, prior to street modification. 

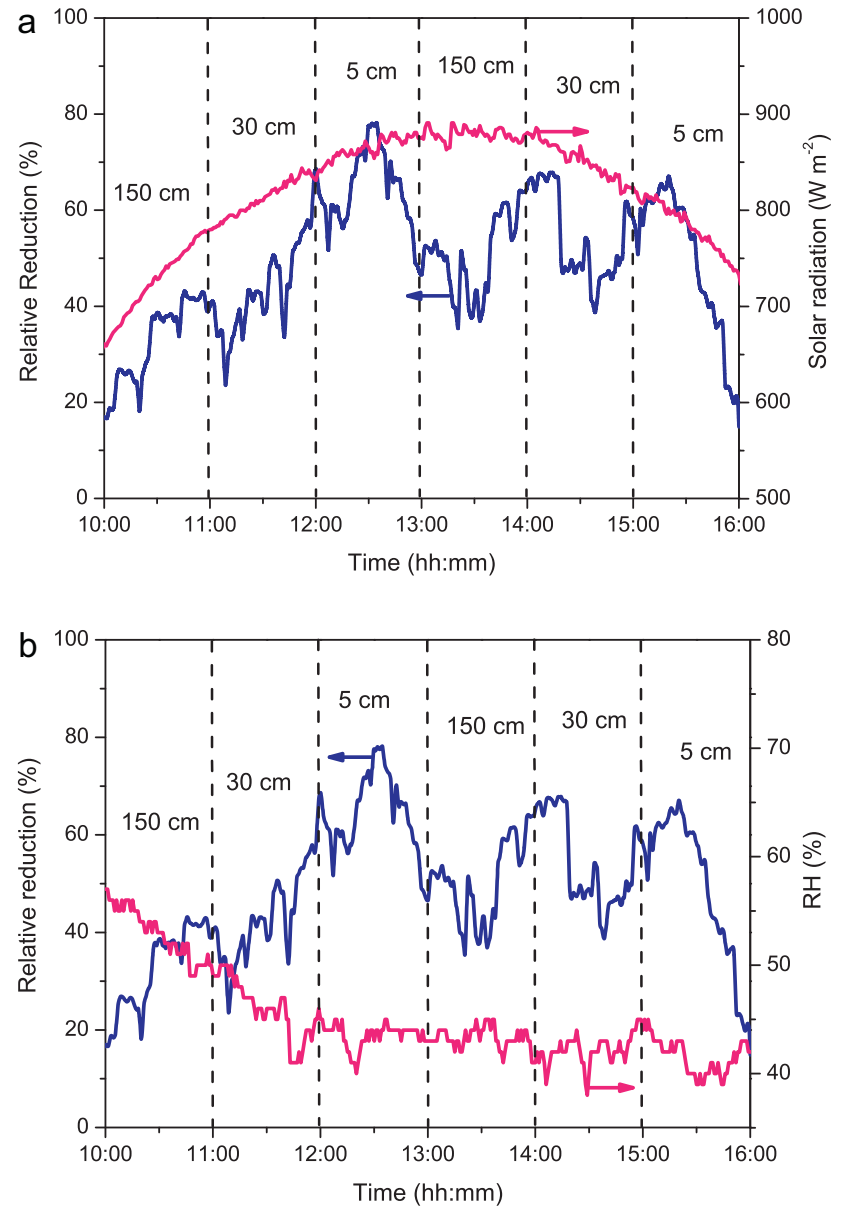

Fig. 5. Relative reduction for the $\mathrm{NO}_{x}$ concentration measured in the $\mathrm{DeNO}_{x}$ street and in the Control street at different height sampling versus: (a) the solar radiation, (b) the relative humidity, 3rd of June, 2010, after first coating.

$\mathrm{NO}_{x}$ concentration in the DeNO $\mathrm{N}_{x}$ and in the Control street were similar, indicating that both street present similar conditions of pollution.

After the application of a first photocatalytic coating on 21st of May 2010, with a $\mathrm{NO}_{x}$ degradation performance at lab scale of $39 \%$, another air quality measurement was performed the 3rd of June 2010. This day was perfectly sunny. The maximum irradiance registered around the solar noon $(13: 30 \mathrm{pm})$ was $890 \mathrm{~W} / \mathrm{m}^{2}$. The wind speed was approximately perpendicular to the Castorweg street, mainly from the ENE and NE, with gusts of $4 \mathrm{~m} / \mathrm{s}$ and an average wind speed of $1.9 \mathrm{~m} / \mathrm{s}$. The relative humidity varied from $55 \%$ in the morning to $40 \%$ in the afternoon.

Fig. 5 shows the relative reduction calculated with the average $\mathrm{NO}_{x}$ concentration measured in the DeNO${ }_{x}$ street and in the Control street. Both sampling positions, in the Control and in the $\mathrm{DeNO}_{x}$ street, were at 150,30 and $5 \mathrm{~cm}$ height, starting at $150 \mathrm{~cm}$ and changing the height every hour. A reduction of approximately 45.5\% for the $\mathrm{NO}_{x}$ concentration in the DeNO ${ }_{x}$ street can be seen here, but it changes according the sampling height. When the sampling height is closer to the photocatalytic pavement, the difference between the $\mathrm{NO}_{x}$ concentrations is higher. Measuring at $5 \mathrm{~cm}$ from the surface, the $\mathrm{NO}_{x}$ reduction is increased approximately $37 \%$ and $30 \%$ respect to the measurements done at $150 \mathrm{~cm}$ and at $30 \mathrm{~cm}$ respectively. In addition, in Fig. 5 (a) and (b) the solar radiation and relative humidity respectively are shown for that day. When the solar radiation increases along the day and the atmosphere becomes dryer, the $\mathrm{NO}_{x}$ reduction increases. This is in concordance
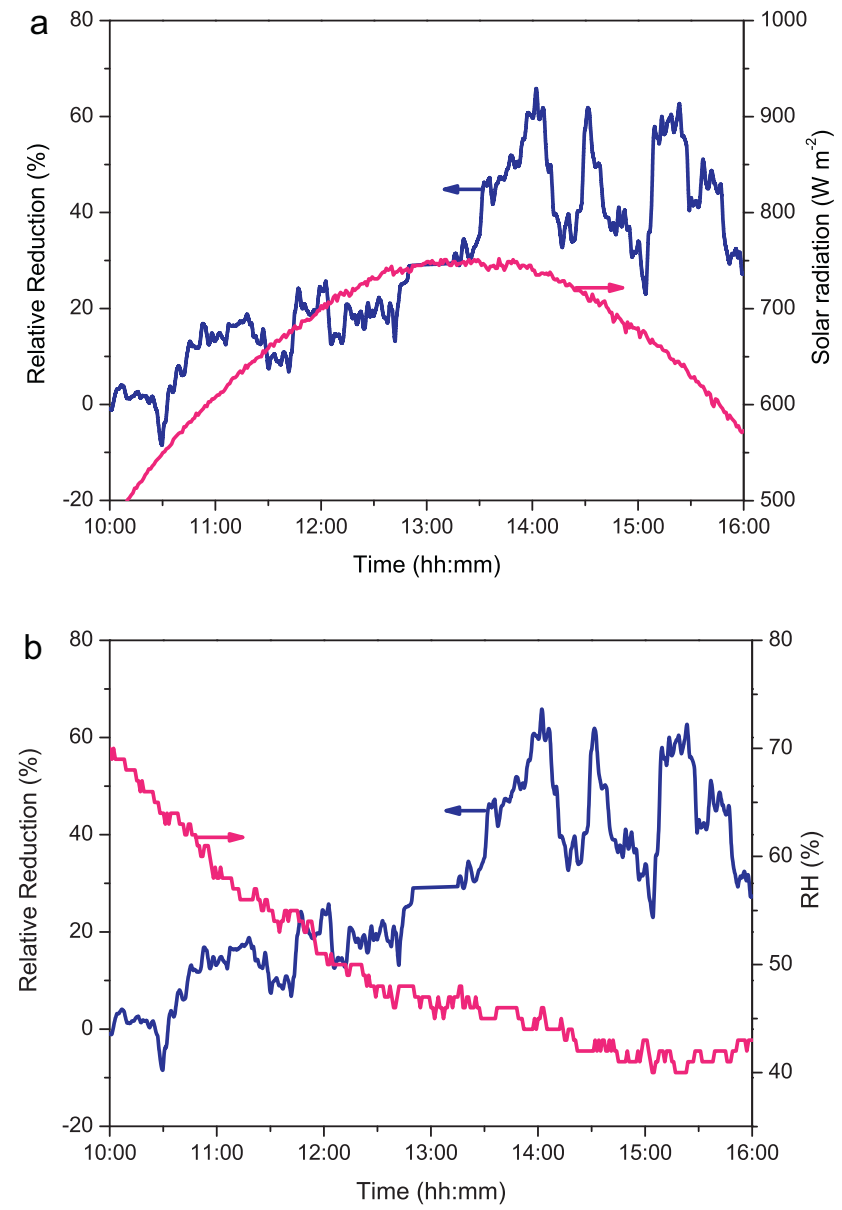

Fig. 6. Relative reduction for the $\mathrm{NO}_{x}$ concentration measured in the $\mathrm{DeNO}_{x}$ street and in the Control street versus: (a) the solar radiation, (b) the relative humidity, 6th of September, 2010, after second coating.

with the lab tests done by [28], where the effect of different parameters over the photocatalytic $\mathrm{NO}_{x}$ degradation was studied.

The 6th of September, immediately after the application of the second photocatalytic coating, was also a sunny day. The maximum irradiance registered was $750 \mathrm{~W} / \mathrm{m}^{2}$, because it was late in the summer. The wind speed was a little high, mainly from the $\mathrm{SE}$, along the Castorweg, with gusts of $5 \mathrm{~m} / \mathrm{s}$. During this day the relative humidity was higher than in June, from $70 \%$ to $40 \%$.

The $\mathrm{NO}_{x}$ reduction by the air purifying street that day can be observed in Fig. 6. The $\mathrm{NO}_{x}$ concentration difference is almost negligible in the morning, but it increases significantly in the afternoon. This can be explained observing Fig. 6(b), where the relative humidity in the morning was high and therefore the $\mathrm{NO}_{x}$ degradation rate was low, but also the $\mathrm{DeNO}_{x}$ blocks were probably wet because of the dew in the morning. In the afternoon, when the irradiance increased (Fig. 6(a)), the relative humidity became lower and most likely the blocks were dry, the $\mathrm{NO}_{x}$ reduction increased till almost $55 \%$.

The other results performed after the first and second coatings are not shown in details here, although some general analysis can be made in order to understand the obtained results. The day of the coating application $(21 / 05 / 2010)$ the $\mathrm{NO}_{x}$ concentration was measured with the $\mathrm{NO}_{x}$ analyzer, showing that when the coating was applied in front of the sampling place a significant $\mathrm{NO}_{x}$ reduction was observed. A few days after the coating application, 4/6/2010, again a significant $\mathrm{NO}_{x}$ decrease was found as on 3/6/2010. Two of this days were rainy (26/05/2010 and 21/10/2010) and therefore no positive results were found. During these two days the 
$\mathrm{NO}_{x}$ concentration in the $\mathrm{DeNO}_{x}$ street was not reduced and was even higher than in the Control street because the surface was wet and the contaminants could not reach the active sites. On the other hand, the result on 15/09/2010 shows again a higher $\mathrm{NO}_{x}$ concentration in the $\mathrm{DeNO}_{x}$ street than in the Control street because this day was particularly and extremely windy (with gusts of $6.2 \mathrm{~m} / \mathrm{s}$ ) and the contamination probably came from other streets (e.g. Deurningerstraat, Fig. 2) as well as the residence time of the air over the surface was very short without the possibility to react [30]. On 13/09/2010 and on 22/09/2010 the relative humidity was very high $(97 \%)$ in the morning and the street surface was wet. Especially on $22 / 09 / 2010$, despite it was a sunny day and good results were expected, the relative humidity was pretty high preventing the $\mathrm{NO}_{x}$ reaction with the photocatalytic surface. Then, in the afternoon of both days, the results improved significantly when the relative humidity decreased and the surface dried. On $8 / 10 / 2010$, despite it was a cloudy day, a very good degradation was found since that day the air sample was taken closer to the surface the whole day (at $30 \mathrm{~cm}$ ). Finally, on 11/10/2010, the performance was again lower probably because the temperature dropped and also probably because after several days with sun the nitrates were accumulated over the surface reducing the photocatalytic efficiency [35].

The measurement data collected at all other days and their pertaining discussion can be found in a detailed report [36]. In this reference also more exhaustive specifications of the used equipment, measurements strategies, etc. can be found.

\section{Conclusions}

A demonstration project of the air purifying pavement was done in the city of Hengelo (The Netherlands) in the Castorweg street, where photocatalytic active blocks were applied in the road. The air quality monitoring was performed from the December 2008, so prior to the application of the photocatalytic surface to July 2011 after the application of two photocatalytic coatings. The $\mathrm{NO}_{x}(\mathrm{NO}$ and $\left.\mathrm{NO}_{2}\right)$ concentration in the modified street $\left(\mathrm{DeNO}_{x}\right.$ street) and in a Control street was measured as well as weather parameters (temperature, solar radiation, UV radiation, relative humidity, wind speed) and the ozone concentration. The main conclusions are as follows:

(1) The pavement was applied with blocks containing relatively little photocatalytic powder $(0.59 \%, \mathrm{w} / \mathrm{w})$, and the $\mathrm{NO}_{x}$ reducing effectiveness was poor (at lab scale and at street scale). After the application of the first coating the effectiveness was high, but this decreased in time. After the application of the second coating, the blocks performed well again. Also this second coating lost its abating ability in time.

(2) Following point 1), a clear and direct relation between the $\mathrm{NO}_{x}$ abating ability of blocks in the lab (taken from the street and determined according to ISO 22197-1:2007 [26])) and the performance of the street could be observed. And this $\mathrm{NO}_{x}$ reducing ability is directly related to the amount of photocatalyst present on the surface of the block.

(3) Just after the application of the first coating and later, after the application of the second coating, in the lab the blocks featured a $\mathrm{NO}_{x}$ reducing ability of around $38 \%$ according to ISO $22197-$ $1: 2007$ [26] using a surface of $100 \mathrm{~mm} \times 200 \mathrm{~mm}$. In the DeNO street, the $\mathrm{NO}_{x}$ concentration was, on average, 19\% (considering the whole day) and $28 \%$ (considering only afternoons) lower than the obtained values in the Control street. The pertaining standard deviations $(\sigma)$ amount $18 \%$ and $20 \%$, respectively. Under ideal weather conditions (high radiation and low relative humidity), a concentration decrease of $45 \%$ could be observed.
(4) The measurements were done at heights of $5 \mathrm{~cm}, 30 \mathrm{~cm}$ and $150 \mathrm{~cm}$, the same period of time at each height, and the reductions under point 3 ) constitute an average. At a height of $5 \mathrm{~cm}$ the $\mathrm{NO}_{x}$ reduction is about $1 / 3$ higher than at $150 \mathrm{~cm}$.

(5) Measurements prior to the street modification (4 days), after the modification with the almost non-performing blocks ( 7 days), after the first and second coatings lost their abating ability ( 3 days), and when the weather conditions limited the photocatalytic action of the blocks (2 days) are all considered as the "non-active DeNO$_{x}$ street". These non-active situations reveal that the $\mathrm{NO}_{x}$ concentration in the $\mathrm{DeNO}_{x}$ street is almost the same, only $0.42 \%(\sigma=17 \%)$ higher, as in the Control street. ${ }^{1}$

Though the number of measurements reported here is limited and the spreads in results large (reflected in the large $\sigma$ ), and that the project has been executed with relatively modest means; one can tentatively conclude that a photocatalytically active street can reduce $\mathrm{NO}_{x}$ concentrations tangibly. They also support the view to continue the measurements, and/or to set up a comparable new experiment in another street, but then employing continuously (all days and nights) air-monitoring stations during a period of one year or so. The valuable experiences gained with the set-up and execution of the Hengelo project, reported here, will serve such a new project.

\section{Acknowledgements}

The authors wish to express their thanks to the following sponsors of the research group: Rijkswaterstaat Centre for Infrastructure, Graniet-Import Benelux, Kijlstra Betonmortel, Struyk Verwo, Attero, Enci, Provincie Overijssel, Rijkswaterstaat Directie Zeeland, A\&G Maasvlakte, BTE, Alvon Bouwsystemen, V.d. Bosch Beton, Selor, Twee "R" Recycling, GMB, Schenk Concrete Consultancy, Intron, Geochem Research, Icopal, BN International, APP All Remove, Consensor, Eltomation, Knauf Gips, Hess ACC Systems and Kronos (in chronological order of joining).

Also the authors would like to acknowledge the Provincie of Overijssel for the financial support, especially Peter Moorman, Rob van Arkel, Francina Geschiere and Harrie Hamstra. The Municipality of Hengelo and its employees, especially Raymond Frank, Richard Geerdink, Caspar ter Brake and Helene Bouwhuis are thanked for setting up the project, making a street available, and helping with the execution of the experiments. Struyk Verwo Groep/Marlux, especially Joop Dijkmans, Rinke Veld, Eric Peeters, Peter van Mierlo and Marc Lambrecht, are thanked for providing the DeNO $_{x}$ blocks, the application of the coatings, and providing an $\mathrm{NO}_{x}$ analyzer. Anne Beeldens (Catholic University of Louvain), Jan Duyzer (TNO), Dave de Jonge and Jaap Visser (Amsterdam Municipal Health Service, "GGD Amsterdam") and Ruben Beijk (RIVM) are acknowledged for sharing their experience with outdoor air quality measurements and their advice.

The Castorweg's residents are thanked for their valuable help during the project. Martin Hunger, Götz Hüsken, Jeroen Overman, Qingliang Yu, Przemek Spiesz, Stepan Lorencik and Peter Cappon are acknowledged for the assistance during the measurements, indoor and outdoor.

\footnotetext{
1 When two outliers would be included, this number is $5.8 \%(\sigma=22 \%)$, so then $\mathrm{DeNO}_{\mathrm{x}}$ street is substantially more contaminated in the zero situation. This percentage could be added to the reductions mentioned under point 4 ).
} 


\section{References}

[1] The council of the European Union, 'Council Directive 1999/30/EC (1999) relating to limit values for sulphur dioxide, nitrogen dioxide and oxides of nitrogen, particulate matter and lead in ambient air', 1999.

[2] T. Ibusuki, K. Takeuchi, Removal of low concentration nitrogen oxides through photoassisted heterogeneous catalysis, J. Mol. Catal. 88 (1994) 93-102.

[3] K. Hashimoto, K. Wasada, M. Osaki, E. Shono, K. Adachi, N. Toukai, H. Kominami, Y. Kera, Photocatalytic oxidation of nitrogen oxide over titania-zeolite composite catalyst to remove nitrogen oxides in the atmosphere, Appl. Catal. B: Environ. 30 (2001) 429-436.

[4] J.S. Dalton, P.A. Janes, N.G. Jones, J.A. Nicholson, K.R. Hallam, G.C. Allen, Photocatalytic oxidation of $\mathrm{NO}_{x}$ gases using $\mathrm{TiO}_{2}$ : A surface spectroscopic approach, Environ. Pollut. 120 (2002) 415-422.

[5] H. Ichiura, T. Kitaoka, H. Tanaka, Photocatalytic oxidation of $\mathrm{NO}_{x}$ using composite sheets containing $\mathrm{TiO}_{2}$ and a metal compound, Chemosphere 51 (2003) $855-860$.

[6] S. Devahasdin, C. Fan, J.K. Li, D.H. Chen, $\mathrm{TiO}_{2}$ photocatalytic oxidation of nitric oxide: transient behavior and reaction kinetics, J. Photochem. Photobiol. A: Chem. 156 (2003) 161-170.

[7] Y.M. Lin, Y.H. Tseng, J.H. Huang, C.C. Chao, C.C. Chen, I. Wang, Photocatalytic activity for degradation of nitrogen oxides over visible light responsive titaniabased photocatalysts, Environ. Sci. Technol. 40 (2006) 1616-1621.

[8] B.N. Shelimov, N.N. Tolkachev, O.P. Tkachenko, G.N. Baeva, K.V. Klementiev, A.Y. Stakheev, V.B. Kazansky, Enhancement Effect of $\mathrm{TiO}_{2}$ dispersion over alumina on the photocatalytic removal of $\mathrm{NO}_{x}$ admixtures from $\mathrm{O}_{2}-\mathrm{N}_{2}$ flow, J. Photochem. Photobiol. A: Chem. 195 (2008) 81-88.

[9] A. Fujishima, K. Hashimoto, T. Watanabe, $\mathrm{TiO}_{2}$ photocatalysis fundaments and applications, Chiyoda-ku, Tokyo, 1999.

[10] M. Lackhoff, X. Prieto, N. Nestle, F. Dehnb, R. Niessner, Photocatalytic activity of semiconductor-modified cement-influence of semiconductor type and cement ageing, Appl. Catal. B: Environ. 43 (2003) 205-216.

[11] C.S. Poon, E. Cheung, NO removal efficiency of photocatalytic paving blocks prepared with recycled materials, Const. Build. Mater. 21 (2007) 1746-1753.

[12] H. Wang, Z. Wu, W. Zhao, B. Guan, Photocatalytic oxidation of nitrogen oxides using $\mathrm{tio}_{2}$ loading on woven glass fabric, Chemosphere 66 (2007) 185-190.

[13] T. Maggos, G.J. Bartzis, M. Liakou, C. Gobin, Photocatalytic degradation of $\mathrm{NO}_{x}$ gases using $\mathrm{TiO}_{2}$-containing paint: A real scale study, J. Hazard. Mater. 146 (2007) 668-673.

[14] T. Maggos, J.G. Bartzis, P. Leva, D. Kotzias, Application of photocatalytic technology for $\mathrm{NO}_{x}$ removal, Appl. Phys. A Mater. 89 (2007) 81-84

[15] A. Beeldens, Air purification by road materials: results of the test project in Antwerp, in: P. Baglioni, L. Cassar (Eds.), Proceedings International RILEM Symposium on Photocatalysis, Environment and Construction Materials-TDP, RILEM Publications, Bagneux, 2007, pp. 187-194.

[16] R. Amadelli, L. Samiolo, Concrete containing $\mathrm{TiO}_{2}$ : an overview of photocatalytic $\mathrm{NO}_{x}$ abatement, in: P. Baglioni, L. Cassar (Eds.), Proceedings International RILEM Symposium on Photocatalysis, Environment and Construction Materials-TDP, RILEM Publications, Bagneux, 2007, pp. 155-162.

[17] G. Hüsken, M. Hunger, H.J.H. Brouwers, Comparative study on cementitious products containing titanium dioxide as photo-catalyst, in: P. Baglioni, L. Cassar (Eds.), Proceedings International RILEM Symposium on Photocatalysis, Environment and Construction Materials-TDP, RILEM Publications, Bagneux, 2007, pp. 147-154.
[19] M. Kawakami, T. Furumura, $\mathrm{H}$. Tokushige, $\mathrm{NO}_{x}$ removal effects and physical properties of cement mortar incorporating titanium dioxide powder, in: P. Baglioni, L. Cassar (Eds.), Proceedings International RILEM Symposium on Photocatalysis, Environment and Construction Materials-TDP, RILEM Publications, Bagneux, 2007, pp. 163-170.

[20] Dutch Air Quality Innovation Programme (IPL), http://www.ipl-airquality.nl/

[21] Final report NR2C New Road Construction Concepts Towards reliable, green, safe \& smart and human infrastructure in Europe, 2008, http://nr2c.fehrl.org/?m=23\&id_directory=789

[22] Photocatalytic Innovative Coverings Applications for Depollution (PICADA) http://www.picada-project.com/domino/SitePicada/Picada.nsf?OpenDataBase

[23] T. Maggos, A. Plassais, J.G. Bartzis, C. Vasilakos, N. Moussiopoulos, L. Bonafous, Photocatalytic degradation of $\mathrm{NO}_{x}$ in a pilot street canyon configuration using $\mathrm{TiO}_{2}$-mortar panels, Environ. Monit. Assess. 136 (2008) 35-44.

[24] G.L. Guerrini, E. Peccati, Photocatalytic cementitious roads for depollution, in: P. Baglioni, L. Cassar (Eds.), Proceedings International RILEM Symposium on Photocatalysis, Environment and Construction Materials-TDP, RILEM Publications, Bagneux, 2007, pp. 179-186.

[25] M.M. Ballari, H.J.H. Brouwers, Air quality monitoring protocol in castorweg for the demonstration air purifying pavement project in Hengelo city, Department of Construction Management \& Engineering, Faculty of Engineering Technology, University of Twente, Enschede, The Netherlands, 2009.

[26] ISO 22197-1. Fine Ceramics (Advanced Ceramics, Advanced Technical Ceramics ) - Test Method for Air Purification Performance of Semiconducting Photocatalytic Materials - Part 1: Removal of Nitric Oxide, first edition, 2007.

[27] J.V. Staub de Melo, G. Trichês, P.J.P. Gleize, J. Villena, Development and evaluation of the efficiency of photocatalytic pavement blocks in the laboratory and after one year in the field, Const. Build. Mater. 37 (2012) 310-319.

[28] M.M. Ballari, M. Hunger, G. Hüsken, H.J.H. Brouwers, Modelling and experimental study of the $\mathrm{NO}_{x}$ photocatalytic degradation employing concrete pavement with titanium dioxide, Catal. Today 151 (2010) 71-76.

[29] M.M. Ballari, Q.L. Yu, H.J.H. Brouwers, Experimental study of the $\mathrm{NO}$ and $\mathrm{NO}_{2}$ degradation by photocatalytically active concrete, Catal. Today 161 (2011) $175-180$.

[30] J.V. Staub de Melo, G. Trichês, Evaluation of the influence of environmental conditions on the efficiency of photocatalytic coatings in the degradation of nitrogen oxides $\left(\mathrm{NO}_{x}\right)$, Build. Environ. 49 (2012) 117-123.

[31] N. Moussiopoulos, P. Barmpas, I. Ossanlis, J. Bartzis, Comparison of numerical and experimental results for the evaluation of the depollution effectiveness of photocatalytic coverings in street canyons, Environ. Model. Assess. 13 (2008) 357-368.

[32] Overman H.T.J., Simulation model for $\mathrm{NO}_{x}$ distributions in a street canyon with air purifying pavement, Master Thesis, Department of Construction Management \& Engineering, Faculty of Engineering Technology, University of Twente, Enschede, the Netherlands, 2009.

[33] S. Marsili-Libelli, Simplified kinetics of tropospheric ozone, Ecol. Model. 84 (1996) 233-244.

[34] P. Pichat, J. Disdier, C. Hoang-Van, D. Mas, G. Goutailler, C. Gaysse, Purification/deodorization of indoor air and gaseous effluents by $\mathrm{TiO}_{2}$ photocatalysis, Catal. Today 63 (2000) 363-369.

[35] N.S. Allen, M. Edge, J. Verran, J. Stratton, J. Maltby, C. Bygott, Photocatalytic titania based surfaces: environmental benefits, Polym. Degrad. Stab. 93 (2008) 1632-1646.

[36] M.M. Ballari, H.J.H. Brouwers, Demonstration project of air-purifying pavement in Hengelo, The Netherlands, 2nd ed., Rep. Nr. BWK2011.1098, Department of the Built Environment, Eindhoven University of Technology, Eindhoven, The Netherlands, 2011. 